\begin{tabular}{|c|c|c|}
\hline 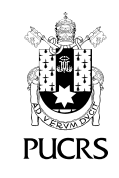 & $\begin{array}{l}\text { ESCOLA DE } \\
\text { HUMANIDADES }\end{array}$ & $\begin{array}{l}\text { Revista Digital do Programa de Pós-Graduação em Letras da PUCRS } \\
\text { Letrônica, Porto Alegre, v. 13, n. 1, p. 1-17, jan.-mar. } 2020 \\
\text { e-ISSN: } 1984-4301\end{array}$ \\
\hline de) $h$ ttp: //dx & $\mathrm{rg} / 10.15448 / 1984-4301.2020 .1 .35107$ & \\
\hline
\end{tabular}

\title{
A personagem feminina em Margarida La Rocque: a ilha dos demônios, de Dinah Silveira de Queiroz ${ }^{1}$
}

\author{
The female character in Margarida La Rocque: a ilha dos \\ demônios, by Dinah Silveira de Queiroz
}

\author{
Ana Cristina Steffen ${ }^{2}$ \\ orcid.org/0000-0003-2243-7679 \\ ana.steffen@acad.pucrs.br
}

Recebido em: 29 jul. 2019. Aprovado em: 9 dez. 2019 Publicado em: 7 abr. 2020
Resumo: Este trabalho tem como objetivo central analisar a protagonista do romance Margarida La Rocque: a ilha dos demônios (1949), de Dinah Silveira de Queiroz. A autora produziu uma vasta e diversificada obra - que transitou do romance histórico à ficção científica. As narrativas da escritora, em geral, são centradas em personagens femininas e, em Margarida, essa personagem mostra-se uma mulher que busca novos caminhos possiveis para si. Dessa forma, o romance coloca-se dentre aqueles pertencentes a uma fase de transição em que começavam a ser postas em discussão as assimetrias das relações de gênero. Sendo assim, a fundamentação teórica desta pesquisa consiste em grande parte na teoria e na critica feminista; para tal, foram privilegiadas estudiosas brasileiras como Rita Schmidt, Constância Lima Duarte, Ruth Silviano Brandão, dentre outras. Mas foram utilizadas, também, autoras como Simone de Beauvoir, Elaine Showalter, além do estudo de Joanne Frye sobre a narradora-personagem feminina.

Palavras-chave: Dinah Silveira de Queiroz. Margarida La Rocque: a itha dos demônios. Teoria e crítica feminista. Literatura brasileira.

Abstract: This work has as main objective to analyze the main character of the novel Margarida La Rocque: a ilha dos demônios (1949), by Dinah Silveira de Queiroz. The author produced wide and diversified work - which transited from historical novel to scientific fiction. The narratives of the writer, in general, are centered in female characters, and, in Margarida, this character shows herself a woman who seeks new possible paths for herself. This way, the novel is among those ones belonging to a transition phase in which the asymmetries of gender relations were beginning to be put under discussion. Thus, the theoretical foundation of this research consists largely of feminist theory and criticism; for this, Brazilian scholars such as Rita Schmidt, Constância Lima Duarte, Ruth Silviano Brandão have been privileged, among others. But authors such as Simone de Beauvoir, Elaine Showalter, were also used, besides the study of Joanne Frye about the female narrator-character.

Keywords: Dinah Silveira de Queiroz. Margarida La Rocque: a ilha dos demônios. Feminist theory and criticism. Brazilian literature.

No início de 2019 a primeira edição de Margarida La Rocque: a ilha dos demônios completou 70 anos. O romance é o segundo de autoria da paulista Dinah Silveira de Queiroz (1911-1982) que, em uma carreira literária de mais de 40 anos, produziu uma vasta obra que passou pelo romance histórico, crônica jornalística, teatro, ficção cientíica, conto. Ademais, é importante recuperar que Dinah teve uma intensa atuação nos meios culturais e intelectuais de sua época, além de ter dado forte
Artigo está licenciado sob forma de uma licença Creative Commons Atribuição 4.0 Internacional.

Este trabalho é parte dos resuldos da dissertação "Quando a mulher tem voz : a narradora-personagem de Margarida La Rocque a ilha dos demônios, de Dinah Silveira de Queiroz" (2019), realizada com bolsa do Conselho Nacional de Desenvolvimento Científico e Tecnológico (CNPq).

Pontifícia Universidade Católica do Rio Grande do Sul (PUCRS), Porto Alegre, RS, Brasil. 
contribuição para que fosse permitido o ingresso de mulheres na Academia Brasileira de Letras Dinah foi a segunda "imortal" do gênero feminino, eleita em 1980 para a cadeira de número sete. Os romances de Queiroz, de maneira geral, têm como centro as personagens femininas; em Margarida. isso não é diferente: a protagonista, homônima ao romance, é também a narradora de sua própria história e carrega uma série de características que vão na contramão dos estereótipos femininos repetidamente utilizados no fazer literário. Por essas razões, a obra se mostra como integrante de uma fase de transição da literatura brasileira na qual se iniciava o debate em torno das questões de gênero, da representação das personagens femininas e da realidade da mulher. Assim sendo, o objetivo principal deste trabalho é analisar a personagem feminina que protagoniza o romance e, dessa forma, expor de que maneira Margarida se constitui como uma das obras do referido periodo transitório - apontando, inclusive, suas limitações no que diz respeito a isso. Para esse estudo, serão utilizados principalmente aparatos da teoria e da critica feminista, bem como outros textos que se mostraram proficuos a esta pesquisa.

Margarida La Rocque se passa no século XVI e, conforme revelado em nota de apresentação, "foi inspirado numa breve passagem da 'cosmografia' do padre André Thevet3" (QUEIROZ, 1991, p. 1). Sua primeira parte, intitulada "A profecia", é constituida por 10 capítulos. Nela, a protagonista encontrase em um convento narrando sua história a um padre que ouve sem responder - modo como permanece ao longo de todo romance. Margarida faz um relato de sua vida, e o ponto inicial de sua narrativa é a gravidez de sua mãe, quando uma tia sonha que a criança em gestação iria em vida ao inferno. Dada a profecia, Margarida cresce cercada de cuidados por seus pais e por sua aia, Juliana. Aos 19 anos, conhece e casa-se com Cristiano, um aventureiro que participa de expedições maritimas à procura de riquezas em "novas terras". Após o casamento, Margarida deixa a pequena vila na França onde morava e muda-se para uma rica residência em Paris. Seu marido, passado algum tempo, parte para a América. Entediada e aflita com a demora de Cristiano, ela convence Roberval, um primo seu, a levála em uma expedição à Nova França, onde ela espera reencontrar o esposo. Durante a viagem, porém, apaixona-se e torna-se amante ${ }^{4}$ de um dos tripulantes, João Maria. O envolvimento dos dois é descoberto por Roberval, que decide punir Margarida abandonando a ela e a Juliana em uma itha que carrega a reputação de ser habitada unicamente por demônios.

A segunda e última parte, intitulada "O julgamento de Deus", é formada por 51 breves capitulos, durante os quais é narrada a busca pela sobrevivência na ilha dos demônios. João Maria escapa da prisão que the foi impelida no navio e, a nado, vai ao encontro de Margarida na ilha. Durante o período em que lá estão, Margarida se descobre grávida do amante. Os conflitos entre ela, Juliana e João Maria são intensificados, motivados pelas dificuldades na ilha e pelos ciúmes de Margarida em relação a sua aia. É também nesse momento da narrativa que seres estranhos, como a lebre Filho e a Dama Verde, manifestam-se e comunicam-se com Margarida. Ao fim do romance, tendo morrido o seu filho, Juliana e João Maria, Margarida é resgatada por pescadores que a deixam no convento onde está a contar a sua história ao padre.

A publicação de Margarida La Rocque, em 1949, é constituinte da marca do surgimento de outros caminhos possiveis para a mulher. $\mathrm{Na}$ literatura brasileira, isso já vinha se manifestando desde, por exemplo, O quinze (1930), de Rachel de Queiroz, ou ainda antes, com Celeste (1893), de Maria Benedita Bormann. Segundo Schmidt, o romance de Bormann "atualiza os primeiros sinais de desarticulação das convenções de representação da identidade feminina tanto no quadro da ficção culturalmente herdada quanto no do processo de construção do sujeito social"

\footnotetext{
3 André Thevet (1502-1592) foi um frade franciscano francês, cosmógrafo, escritor e cavaleiro do Santo Sepulcro. Esteve no Brasil entre novembro de 1555 e janeiro de 1556, e sobre a sua estada escreveu as obras As singularidades da França Antártica, de 1558, e Cosmografia universal, de 1575 (CALLADO, 2009).

4 A designação "amante" será utilizada ao longo deste trabalho em alusão a João Maria pois o personagem é assim referido no romance.
} 
(SCHMIDT, 2017, p. 325). Esses primeiros sinais de desarticulação, presentes em Celeste, ampliamse com a chegada do século XX. Em O quinze, eles tornam-se ainda mais evidentes, sobretudo quando sua protagonista rejeita uma proposta de casamento, optando por ficar solteira. Segundo Duarte (2016, p. 16), "suas personagens não temem o enfrentamento e rompem com os estereótipos de delicadeza, submissão e sentimentalismo, então impostos à mulher". Para Silva (2009), a década de 1930 é apontada como um periodo em que a produção de autoria feminina se encontra em um estágio de maturidade, "tanto pela qualidade dessa produção quanto pelo número de mulheres que atuam como escritoras. Desse periodo fazem parte as poetisas Cecilia Meireles, Henriqueta Lisboa, bem como as prosadoras Patrícia Galvão (Pagu) e Raquel de Queiroz, entre outras" (SILVA, 2009, p. 45).

Xavier (2002), por outro lado, defende que é somente em 1960, com a publicação de Laços de familia, de Clarice Lispector, que são postas em questão as relações de gênero. Segundo a autora, foi Lispector quem rompeu com a reduplicação de padrões éticos e estéticos de uma literatura com visões limitantes e equivocadas da figura da mulher. Apesar disso, esclarece que "chamar esta etapa de feminista não significa dizer que ela é panfletária; ninguém discute o valor estético da obra de Clarice e, no entanto, ela traz nas entrelinhas uma pungente crítica aos valores patriarcais" (XAVIER, 2002, p. 159). Xavier ainda considera a escritora como "um divisor de águas na trajetória da narrativa brasileira de autoria feminina, uma vez que o discurso obliquo e enviesado de suas narradoras questiona, ironicamente, o sistema de gêneros" (XAVIER, 2002, p. 159). Coelho (1993) também considera a década de 1960 como o periodo inicial de amadurecimento das mulheres escritoras. Para a autora, é nesse momento que se manifesta uma consciência crítica, a partir da qual surgirão nomes como os de Adélia Prado, Clarice Lispector, Hilda Hilst, Lygia Fagundes Telles, Nélida Piñon, dentre outros. A pesquisadora portuguesa Paula Gândara também ressalta a importância dos anos 1960 para a autoria feminina no Brasil, afirmando categoricamente que é somente a partir dessa década que surgem escritoras de grande qualidade. Dentre essas, são citadas Núbia Marques, Rachel Jardim, Lupe Garaude, Myriam Fraga, Heloísa Maranhão e Edla von Steen (GÂADARA, 2002).

Pinto (1990), em estudo sobre o Bildungsroman feminino, cita quatro romances brasileiros que seriam parte de um momento inicial em que surgem outros caminhos possiveis para a mulher. São eles: Amanhecer (1938), de Lúcia Miguel Pereira, As três Marias (1939), de Rachel de Queiroz, Perto do coração selvagem (1944), de Clarice Lispector, e Ciranda de pedra (1954), de Lygia Fagundes Telles. Para a autora, a mudança no desfecho dos dois últimos romances - com novas possibilidades de vida para as personagens - em relação aos dois primeiros - de completo fracasso -, mostram um futuro otimista, indicativo das transformações sociais em curso. Pinto ainda afirma que, em Amanhecer e As três Marias, o início desse processo já está expresso, apesar da marginalização das personagens ao fim das narrativas. Perto do coração selvagem e Ciranda de pedra, por outro lado, estariam inseridos em um periodo de transição, carregado de indefinições, mas no qual já são criadas novas imagens femininas, sugeridas novas possibilidades e abertas diferentes perspectivas - o que contribuiria para o desenvolvimento pessoal e social da mulher (PINTO, 1990).

Muzart (2011), sem especificar uma década, defende que a questão do valor estético deve ser observada nas obras de autoria feminina brasileiras apenas a partir do século XX. Segundo a autora, as narrativas escritas por mulheres antes disso devem obrigatoriamente ser pensadas tendo em consideração o ensino destinado às mulheres nesta época, suas leituras - cerceadas por moral e religião - e a vida restrita ao ambiente doméstico. Pois, "se estudadas conferindo-se o valor estético, esses romances pioneiros serão condenados ao ostracismo" (MUZART, 2011, p. 19). Muzart, assim, atribui às obras de autoria feminina do século XIX, ou mesmo anteriormente a esse periodo, somente um valor histórico. Para Duarte (1987), por outro 
lado, essas obras interessam por permitir novos estudos e consequentemente novas conclusões a respeito da tradição literária feminina. Segundo a autora, um determinado texto não vai deixar de ser mediocre somente por ter sido escrito por uma mulher; ao mesmo tempo, não se vai rotulá-lo antecipadamente de mediocre "porque alguém, sabe-se lá em que circunstâncias, assim o considerou" (DUARTE, 1987, p. 21).

Paralelamente ao avanço da atuação feminina na literatura, se desenvolvem no Brasil os estudos voltados à crítica feminista, principalmente na segunda metade do século XX. Silva (2009) afirma que no País essa crítica se volta basicamente para três questões: a análise da representação feminina na literatura; as discussões em relação a uma possível "linguagem da escritura feminina"; e, por fim, a formação do cânone. Essa última teria por objetivo resgatar obras 'esquecidas' da historiografia tradicional, "contestando, dessa maneira, a ausência da literatura produzida por mulheres" (SILVA, 2009, p. 48). Essa abordagem deriva do que é apontado pela estudiosa americana Elaine Showalter, em A critica feminista no território selvagem (1981). A autora aponta que há duas formas de crítica feminista, sendo a primeira delas ideológica e

[...] diz respeito à feminista como leitora e oferece leituras feministas de textos que levam em consideração as imagens e estereótipos das mulheres na literatura, as omissões e falsos juizos sobre as mulheres na critica, e a mulher signo nos sistemas semióticos (SHOWALTER, 1994, p. 26).

Essa primeira forma começou a mudar seu foco gradualmente a partir da década de 1980 , passando de leituras revisionistas de obras canônicas para "uma investigação consistente da literatura feita por mulheres" (SHOWALTER, 1994, p. 29). Showalter, em outro estudo, propõe, a partir de suas pesquisas sobre a tradição literária inglesa, três categorias para a literatura escrita por mulheres, relacionadas a diferentes momentos temporais. São elas: 1) feminina - ocorrida entre 1840 e 1880, quando as mulheres escreviam em um esforço para se igualarem intelectualmente aos homens, mas sem questionar o papel internalizado, pela cultura masculina, do que seria a natureza feminina; 2) feminista - ocorrida entre 1880 e 1920, paralelamente às reivindicações sufragistas, foi quando as escritoras começaram a questionar as injustiças sofridas pelas mulheres; 3) fêmea - presente desde 1920, fase em que as mulheres rejeitaram tanto a reprodução da cultura masculina quanto o protesto, optando, em vez disso, em utilizar a experiência feminina como fonte para uma arte autônoma (SHOWALTER, 1985). Transferindo essas afirmações para a realidade brasileira, é possivel identificar através da leitura de Margarida La Rocque uma combinação dos três momentos - em maior ou menor medida. Isso se torna bastante expressivo quando se considera o momento da publicação da obra - metade do século XX - quando já se vivenciavam variadas mudanças no que diz respeito à participação da mulher na sociedade e, consequentemente, na literatura.

Segundo Duarte, no texto Feminismo e literatura no Brasil (2003), entre os séculos XIX e XX, observa-se no Brasil a manifestação de quatro ondas do movimento feminista. Na primeira delas, iniciada em torno de 1830, Nísia Floresta Brasileira (1810-1885) publica Direitos das mulheres e injustiça dos homens (1832), considerado o texto fundante do feminismo brasileiro. Data também dessa época a primeira legislação autorizando a abertura de instituições para o ensino de meninas. A segunda onda, por volta de 1870, é marcada pelo surgimento expressivo de jornais e revistas de cunho nitidamente feminista. Desse mesmo período datam as primeiras brasileiras com diploma do ensino superior e também as primeiras manifestações exigindo o voto feminino. Essa exigência, entretanto, ganha força somente na terceira onda, iniciada na década de 1920. E, apenas em 1932, Getúlio Vargas incorporaria ao Código Eleitoral o direito de voto às mulheres, o que viria a se concretizar, no entanto, apenas em 1945 quando as eleições foram retomadas. A quarta onda, por fim, a partir dos anos 1970, foi quando de fato aconteceram as alterações mais radicais nos costumes e as reivindicações mais "ousadas" como o uso da pílula anticoncepcional ou o divórcio 
- passaram a ser incorporadas no cotidiano. A figura da escritora foi parte constitutiva e atuante em todas as quatro ondas e teve seu espaço ampliado conforme também era alargado o espaço da mulher na vida e nos espaços públicos. Na década de 1980 , observa-se uma consolidação e alinhamento do movimento feminista; é também nesse período que surgem os primeiros estudos voltados à mulher e literatura, por meio principalmente do Grupo de Trabalho Mulher na Literatura, da Associação Nacional de Pós-graduação e Pesquisa em Letras e Linguística (ANPOLL), em 1984.

Margarida La Rocque, escrito durante a terceira onda, coloca-se como um romance de uma fase de transição - conforme mencionado por Pinto (1990) - em que surge a discussão a respeito das relações de gênero, mesmo que de forma ainda incipiente. Segundo Coelho (2002), na segunda fase do Modernismo literário - entre os anos 1930 e 1960 - se deu uma

[...] lenta constatação da impossibilidade [de] coexistência harmônica das duas fazes (sic) antagônicas da mulher moderna: a liberada (pelo estudo, profissão ou amor) e a prisioneira "rainha do lar" (ainda valorizada pela sociedade). Antagonismo que resulta no inevitável desencontro amoroso e à frustração da mulher (COELHO, 2002, p. 91).

Relacionado a isso estão dois tipos opostos de personagens femininas (ZOLIN, 2011): as "mulheres-objeto", que exercem papéis que as enredam nas relações conservadoras de gênero, e as "mulheres-sujeito", aquelas com capacidade de traçar rumos "da própria trajetória e desafiarem as manifestações de poder de ideologias semelhantes à patriarcal que, embora não mais encontrem espaço em certos segmentos da nossa sociedade, ainda são dominantes em outros" (ZOLIN, 2011, p. 95). Também segundo Zolin, se a literatura produzida inicialmente por mulheres na tradição brasileira reproduz

[...] os padrões ideológicos referentes ao modo de a mulher estar na sociedade, a produzida a partir de meados do século passado até os anos 80 põe em discussão as relações de gênero, promovendo o desnudamento e a consequente desestabilização da opressão feminina (ZOLIN, 2011, p. 95)
Logo, o romance aqui estudado se reafirma como parte dessa fase transitória pois apresenta uma personagem feminina que desestabiliza os papéis de gênero. Isso porque, se por um lado, ela possui características da mulher-objeto apontado por Zolin, por outro, o que se destaca é a sua atuação como mulher-sujeito. Em Margarida, ao mesmo tempo em que são reutilizados alguns aspectos da sequência básica de ações de uma trajetória feminina que remete à literatura do século XIX - casamento, adultério, loucura e morte (SCHMIDT, 2017) -, também é apresentada uma protagonista que deixa de ser objeto para tornar-se sujeito da narrativa (DUARTE, 2016). Esse processo se dá por uma série de fatores. Um desses, é o questionamento sobre as diferenças nos parâmetros e valores aplicados entre o julgamento do comportamento masculino e do feminino, que se manifesta em diversos trechos da obra; primeiramente, quando Margarida, no início do romance, afirma que nenhum dos moços do seu vilarejo a agradava e relata "meu bom Pai acatava meus desejos de ficar solteira, até encontrar o homem que me agradasse. Isso parecia impróprio às mulheres da aldeia, e muitas me censuravam por querer imitar os homens, casando por meu bel-prazer" (QUEIROZ, 1991, p. 16-17, grifo nosso). Em outras palavras, a protagonista era criticada por ter optado por aguardar até encontrar alguém que a interessasse para se casar. Essa conduta, segundo afirma, era um privilégio apenas masculino e a mulher que assim também agisse pretendia assemelhar-se a um homem, o que é algo condenável. O segundo momento se dá no navio, quando é descoberto por todos o seu relacionamento com João Maria: "De parenta e protegida de Roberval eu passara a réproba, até para aqueles homens assassinos e dementes, vindos diretamente dos cárceres para o navio" (QUEIROZ, 1991, p. 39, grifo nosso). Nessa afirmação fica implícito o sentimento de injustiça vivenciado por Margarida, visto que, conforme a protagonista aponta, a própria tripulação do navio era composta por homens condenados pelos mais diferentes e violentos crimes. E esses mesmos homens são aqueles que agora não só 
aprovam sua punição como também se dirigem a ela como a uma grave criminosa. Assim sendo, fica entrevista a ideia de que uma mulher adúltera é mais condenável do que um homem assassino. O terceiro momento acontece logo a seguir, assim que Margarida e Juliana são deixadas na ilha:

Devia ser dificil escalar a ilha. Sentia-me tal uma sentenciada à fogueira. Antes o fosse! Morreria depressa. "Senhora Margarida", dizia de mim para mim, "dai-me coragem!" Seria, desde o começo do mundo, mais duro o castigo do pecado para a mulher que para o homem? Em breve João Maria, preso, decerto, a bordo, seria perdoado (QUEIROZ, 1991, p. 40).

Nesse trecho mais uma vez é apontada a diferença dos critérios que julgam homens e mulheres. Apenas ela é designada ao exilio na ilha; João Maria foi preso no navio e, provavelmente, se não tivesse ido à sua procura, em pouco tempo seu erro seria esquecido e perdoado. Essa passagem, ainda, faz menção à morte na fogueira, referência à sentença comumente aplicada às mulheres tidas como bruxas durante a Inquisição (HANCIAU, 2004). Visto que a condenação dessas mulheres se dava quase sempre de forma indevida e arbitrária, é reiterada a ideia de injustiça que permeia as diferentes situações em que mulheres estão em julgamento.

Outro fator que torna Margarida um romance participante dessa fase transitória é, reitero, a presença de uma narradora mulher. Isso porque é ela quem conta a própria história, e "é na instância de discurso na qual eu designa o locutor que este se enuncia como 'sujeito'" (BENVENISTE, 1991, p. 288, grifo do autor). Segundo Brandão (2004), as mulheres na literatura foram por muito tempo apenas passageiras da voz alheia, calando assim a própria voz e, consequentemente, calando seus próprios desejos, permanecendo, esses, desconhecidos. A autora também afirma que
É no e do espelho da folha branca do texto que surge esta figura de mulher que circula no imaginário literário e social. Entretanto, a idealização feminina, qualquer que ela seja, sempre cumpre a sentença de morte da mulher. Se ela aceita este lugar, ela aceita a sua petrificação, por mais bela e perfeita que seja a estátua onde ela se erige: aí é o lugar da alienação de seu desejo (BRANDÃO, 2004, p. 13).

Segundo Scholze (2002, p. 175), "as mulheres sofreram ao longo da história um processo de silenciamento e exclusão". O individuo detentor da palavra, aquele que fala, é majoritariamente masculino, seja na literatura, na lei ou na tribuna. A esse sujeito é reservado o lugar de destaque. Essa afirmação pode ser associada com o estudo da pesquisadora Joanne Frye, Living stories, telling lives: women and the novel in contemporary experience (1986), sobre a narradora feminina. Conforme a autora, o narrador em primeira pessoa (ou autodiegético5) feminino constitui em si uma subversão, uma vez que a mulher não é narrada, mas narra com voz própria (FRYE, 1986). Independentemente da nomenclatura utilizada narrador em primeira pessoa ou autodiegético - fato é que a escolha por uma narradora que conta sua história está diretamente relacionada à construção de uma personagem feminina renovadora.

Bournneuf e Ouellet (1976) afirmam que o projeto do escritor e a técnica narrativa por ele utilizada estão indissoluvelmente ligados; em outras palavras, o autor opta por escrever de uma certa maneira, elege um certo tipo de narrador, para se manifestar no mundo de um modo em particular - o que carrega em si uma significação. Nessa forma de narração, encontrada em Margarida La Rocque, são alargadas as possibilidades de representar o feminino, expondo assim o que Frye conceitua como re-emplotment. ou seja, a possibilidade de criação de enredos para uma protagonista mulher que superem aqueles restritos à passividade de papéis românticos ou

\footnotetext{
5 Sobre o narrador em primeira pessoa, Tacca o define como aquele que "participa nos acontecimentos narrados. Essa participação pode assumir: a) um papel protagônico; b) um papel secundário; c) o papel de mero testemunho presencial dos fatos. Nestes casos, o narrador identifica-se com um personagem" (TACCA, 1983, p. 62). Genette [1976?], por outro lado, considera inadequado o uso do termo "narrador em primeira pessoa" - em oposição ao narrador em terceira pessoa ou mesmo segunda pessoa -, pois, segundo ele, "na medida que o narrador pode a todo instante intervir como tal na narrativa, toda a narração é, por definição, virtualmente feita na primeira pessoa" (GENETTE, [1976?], p. 243). Ao apontar essa impropriedade, ele atualiza a nomenclatura do conceito para narrador "homodiegético", ou seja, aquele "presente como personagem na história que conta" (GENETTE, [1976?], p. 244) e, particularizando ainda mais esse conceito, aponta ainda o "autodiegético", narrador que também se constitui não só como personagem, mas também herói da sua própria narrativa. Esses, ainda segundo Genette, seriam opostos ao "heterodiegético", narrador ausente da história.
} 
sexuais (FRYE, 1986). Frye também afirma que o fato de um romance ser enunciado por um "eu" mulher constitui uma ameaça aos privilégios masculinos que tentaram silenciar a voz feminina. Utilizando como exemplo a obra Cassandra, de Christa Wolf, a autora aponta:

When she says "I" in full subjectivity, she disrupts that privileging as she disrupts external notions of essence, of sameness: the culture text of femininity, which has made her, as a woman, into an "object", cannot accommodate her subjective voice and presence. As the "I" speaks for itself and of itself, it necessarily insists on the contradictions between internal and external definitions of self and hence on that "surplus of humanness" that always provides an entry into the future, a resistance to fixity (FRYE, 1986, p. 50)

Para Frye, ainda, o perigo que a literatura ofereceu e oferece à integridade do sistema patriarcal origina-se, então, na voz da mulher, no fato de a mulher ganhar voz. Logo, a subversão teve início assim que uma primeira narradora disse "eu", mesmo em romances de autoria masculina ou que ratificam essa ordem patriarcal. O fato de a mulher dizer "eu", em uma narrativa, contribuiria para subverter as possibilidades de representação literária. E, ainda segundo a autora, isso é relevante por reivindicar o uso histórico dos recursos romanescos em interagir com as experiências vividas de uma forma significativa, usando tais recursos, nesse caso, para entender a vida das mulheres e possibilitando novas interpretações de suas experiências (FRYE, 1986).

Bournneuf e Ouellet afirmam que, em um romance, "cada momento da ação constitui uma situação de conflito, em que as personagens se perseguem, se aliam, ou se confrontam" (BOURNNEUF; OUELLET, 1976, p. 214). Tratando especificamente da personagem protagonista, os autores irão afirmar que é ela quem dá para a ação da narrativa o primeiro impulso dinâmico, ou seja, é a protagonista quem provoca o conflito. Isso acontece pelo "nascer de um desejo, duma necessidade ou, ao contrário, dum temor" (BOURNNEUF; OUELLET, 1976, p. 215). Em Margarida La Rocque, são justamente o desejo e o fascínio da protagonista pelo desconhecido, pelo aventuroso, que impulsionam suas ações e consequentemente a narrativa; diferentemente de como seria previsivel, dado o contexto em que a personagem está inserida, ela não desenvolve nenhum interesse por rotina ou trabalhos caseiros - o que é indicativo do rompimento da protagonista com o ambiente doméstico. Margarida é, inclusive, poupada desse tipo de trabalho ou aprendizado:

\begin{abstract}
Meus Pais, tão bons, facilitavam o gosto que eu tinha por conservar a beleza que Deus me dera. Nos trabalhos de casa, e em outras canseiras, eu era poupada. Tinha, ao contrário das outras jovens do lugar, uma aia para meus serviços. Secretamente, receosos que se cumprisse a tremenda visão que anunciara meu nascimento, meus Pais desejavam dar tudo que tivessem a seu alcance por minha felicidade, e nisso não poupavam sacrifícios. [...] Embora triste com o que murmuram de mim as mulheres, a Mãe, tanto quanto o Pai, não me forçava a aceitar marido. Mas, quando the diziam: "Bom caminho abris para vossa filha: morrereis um dia e, pobre, ela ficará sem saber nem ao menos preparar uma sopa, ou fiar a lã!..." quando lhe diziam essas coisas, ela chorava e sofria (QUEIROZ, 1991, p. 16-17)
\end{abstract}

No século XVI, na Europa, o conhecimento ao qual eram destinadas as moças, independentemente de sua posição social, eram os "saber-fazer confinados ao ambiente doméstico, os que se adquirem em casa com a mãe, que mantêm e salvaguardam as casas cristãs" (SONNET, 1993, p. 141). O ensino desses "saber-fazer" visava preparar as jovens para o futuro cotidiano como mãe de familia: "a cozinha, os cuidados com as crianças mais novas, a manutenção da roupa da casa e de vestir, o manejo do fio, das agulhas, da lã, dos tecidos" (SONNET, 1993, p. 141). A crítica direcionada à mãe de Margarida pelas mulheres do vilarejo, assim, tem origem justamente nessas práticas - que eram o habitual no século em que se passa o romance e que perduraram (e em muito ainda perduram) por muitos outros depois. Margarida, dessa forma, mais uma vez é colocada como uma personagem que destoa do que seria esperado ao comportamento e educação femininos mesmo considerando que essa maneira de agir dos pais da protagonista tenha justificativa na 
profecia que antecedeu o seu nascimento.

Em contrapartida, é possivel entender - ainda que isso não seja claramente informado - que Margarida não sabia ler. Em sua infância, ela ouvia a leitura, feita pela aia Juliana, de "romances de destemidos cavaleiros de eras passadas" (QUEIROZ, 1991, p. 16). Quando adulta, ela continua a ouvir a aia ler e, quando solicitado que ela própria conte as histórias, ela o faz a partir da memória e não da leitura de seus livros. Assim sendo, se por um lado Margarida não teve o aprendizado do 'saber-fazer' comumente destinado às mulheres, por outro, ela também não teve algum tipo de educação que contrariasse essa lógica, como, por exemplo, o conhecimento de escrever e ler. O fato de Margarida ouvir as histórias lidas por Juliana, porém, é uma questão crucial no romance, pois deixa entender que desde criança a personagem teve a curiosidade instigada por histórias aventurescas. E essa descrição da infância, ainda que breve, é significativa quando a consideramos sob o ponto de vista das teorias feministas. Simone de Beauvoir, no clássico O segundo sexo (1949), ao tratar da problemática da mulher casada, afirma que

No terreno da abstração e da lógica, a mulher resigna-se frequentemente a aceitar a autoridade masculina; mas quando se trata de ideias, hábitos que a interessam realmente, ela se opõe com uma tenacidade dissimulada. A influência da infância e da juventude é muito mais profunda nela do que no homem, pelo fato de que ela permanece mais encerrada em sua história individual. Do que adquiriu nesses periodos, geralmente não se desfaz nunca (BEAUVOIR, 2016, p. 251).

Tal qual o descrito por Beauvoir, em Margarida, o interesse adquirido ainda na infância pelas histórias de aventura dos cavaleiros destemidos acompanha a protagonista durante toda a vida. No início da idade adulta, isso se manifesta na escolha do noivo. Depois de ter negado casamento a vários homens de seu vilarejo, não por acaso é o viajante Cristiano quem lhe desperta interesse:

Já estava eu com dezenove anos; e apareceu pela terra um senhor de quem diziam ser muito rico e viajado. Meu Pai por acaso o conheceu, e o levou à nossa casa. Cristiano, tal era o seu nome, contava coisas estranhas, e o Pai o levara lá para que ele me divertisse com suas histórias. Não tanto quanto vós, Padre, mas assim mesmo o bastante para que isso fosse razão de deslumbramento para quem, como eu, só conhecia as estradas e os horizontes da nossa aldeia, Cristiano sabia de paises extraordinários. Ao ouvi-lo narrar suas aventuras, a Mãe, de instante a instante, fazia menção de me tirar da sala. Pareciam-lhe escandalosos certos fatos... Mas, com sinais de aprovação, vendo-me tão divertida, o Pai dizia que ela me deixasse ouvir. Ah, como me agradavam aquelas histórias! Punha-me a conjeturar se aqueles homens que viviam com tanta liberdade, os habitantes das florestas, eram homens mesmo? Acaso o seriam? Sem religião, e com os instintos à solta? Também me fascinavam essas viagens em que nobres e plebeus se misturavam, e de onde qualquer pobre aldeão podia voltar rico e célebre. Tínhamos na familia um parente: Roberval, que começava a ganhar fama, e, se bem que não o conhecesse de perto, sentia orgulho por suas aventuras (QUEIROZ, 1991, p. 17).

Pouco mais adiante, comprova-se que, de fato, para Margarida o atrativo do personagem eram as suas histórias:

Cristiano não era belo. Tinha trinta anos, usava barba em ponta, e suas vestimentas eram mais largas do que se poderia desejar. Estragara os dentes depressa, e falava de maneira autoritária, arrogante mesmo, mas... sem dar por isso, apaixonei-me por suas narrativas, que the davam tanto prestígio (QUEIROZ, 1991, p. 17).

Quando Juliana, ao saber do casamento, implora à Margarida que espere por um marido melhor, ela decide ainda assim casar-se e questiona: "Mas, se eu estava deslumbrada por Cristiano, ou melhor, com o que contava Cristiano, por que haveria de esperar?" (QUEIROZ, 1991, p. 18). Com essa pergunta retórica, assim, a protagonista mais uma vez confirma que o seu encanto é dirigido não ao noivo em si, mas às suas histórias. O fato de Margarida ter podido escolher o marido de sua preferência é outro ponto indicativo de uma personagem detentora de algum nivel de autonomia; diretamente relacionado a isso, e também sintomático de uma personagem autônoma, é o fato de que seu nome - tão importante para a narrativa que intitula o próprio romance - não sofre alterações após o casamento. Mais do que isso: não é feita qualquer menção ao sobrenome de Cristiano.

No entanto, ainda que Margarida tenha se casado conforme o seu interesse, isso não é sinônimo de que o marido não exerceria alguma 
autoridade sobre ela. Segundo Beauvoir, "ainda que tivesse desposado por amor, ao se casar [a mulher] fez dele [o marido] seu senhor; suas relações tornaram-se um dever e muitas vezes ele se apresentou a ela sob a figura de um tirano" (BEAUVOIR, 2016, p. 356-357) - o que acontece no romance. $O$ interesse por Cristiano em pouco tempo transforma-se em temor. Após - casamento, eles e Juliana mudam-se para Paris e o marido passa a restringir a circulação de Margarida na própria casa e a proibi-la de sair enquanto ele estivesse fora:

Trazia [Cristiano] amigos turbulentos à nossa casa. Ceava com eles em separado, obrigando-me a ficar no quarto. Proibia-me de sair à rua, mesmo acompanhada de Juliana. Podeis crer, Padre. Fiquei assustada, quando, certa vez, tendo desobedecido, ele descobriu, e fez estrondar a sua voz raivosa. Muito tempo depois, foi que verifiquei que ele havia passado uma substância branca na sola de minhas sandálias mais bonitas, aquelas reservadas para os passeios em sua companhia. Eu gastara a frágil camada de tintura! (BEAUVOIR, 2016, p. 19).

Esse comportamento confirma outro ponto levantado por Beauvoir: para a autora, o importante para o marido não é que a esposa o ame, mas sim que não o engane e "Ele não hesitará em infligir à mulher um regime debilitante, vedando-lhe o acesso a qualquer cultura, embrutecendo-a com o único fim de salvaguardar sua honra" (BEAUVOIR, 2016, p. 201). Esse mesmo trecho citado do romance ainda revela a desobediência da personagem ao que lhe é imposto, mesmo que volte a acatar as ordens do marido quando é descoberta. Contudo, ela torna a violar a regra ao descobrir que seu primo, Roberval, estava em Paris. Margarida, preocupada devido à demora de Cristiano em retornar, começa a suspeitar de que ele possa ter morrido ou ter sido acometido por uma peste que dizimara parte da equipe do seu navio. Motivada por Juliana, Margarida também suspeita que ele poderia ter permanecido nas novas terras, com alguma "mulher escura e filhos de faces riscadas" (QUEIROZ, 1991, p. 22). Por esses motivos, ela vai ao encontro de Roberval em uma taberna, procurando saber notícias do marido. Seu primo, no entanto, não compartilha das mesmas preocupações:
Roberval não se deixou abater pelas informações que recebeu. Entendidos, que ele consultou, classificaram a peste como produzida pela má alimentação, e portanto, fácil de se evitar [...]. Quando o dia do embarque, no Porto de Saint-Malo, foi conhecido, jurei persuadir meu parente de me levar em sua companhia (QUEIROZ, 1991, p. 21).

Assim, fica evidente que a preocupação e, consequentemente, a busca por Cristiano, servem apenas de pretexto para que Margarida participe da expedição liderada por Roberval - o que a própria confessa neste trecho, quando também confessa não amar o marido:

\begin{abstract}
Se vos abro meu coração, meu Padre, devo dizer que, realmente, não amava meu esposo. Procurava-o sim, ia ao fim do mundo à sua procura, mas agia bem mais como que movida misteriosamente, que por amor a meu marido. Era como se alguém mandasse e eu obedecesse [...] (QUEIROZ, 1991, p. 22).
\end{abstract}

Margarida, ao fim de muita insistência, convence Roberval a levá-la em viagem. Ele, no entanto, faz um alerta ao contar a história de uma outra mulher admitida em seu navio. Segundo ele, a presença de uma velha senhora, "feia, tão seca como um peixe seco" (QUEIROZ, 1991, p. 21) gerou tantos conflitos entre os homens da expedição que ele não teve alternativa senão deixá-la em uma ilha no meio do caminho. Sobre esse episódio, conta Roberval:

\begin{abstract}
- Sabeis, Margarida de La Rocque, que há um costume entre nós, gente do mar. É o julgamento, ou a punição, mas "dada por Deus". Deixamos criaturas em sítios ermos, é verdade. Mas elas conservam armas, e algum alimento. Se não tiverem de morrer, se as ajudar a graça de Deus - então é simples, elas se salvam! (QUEIROZ, 1991, p. 21).
\end{abstract}

Margarida, que posteriormente sofrerá a mesma punição da velha senhora, consegue salvar-se, o que, segundo a fala de Roberval, significa ter recebido ajuda da graça divina. $O$ fato de a personagem não ser destinada à morte - o que, caso acontecesse, completaria a já mencionada trajetória feminina que remete à literatura do século XIX - é outro aspecto que indica transformação no percurso da personagem feminina. Por outro lado, é notório que Margarida carrega sentimentos 
conflituosos em relação ao que se passou. No começo da obra, a personagem deixa claro ao padre que o seu relato não é uma confissão, o que denota ausência de arrependimento:

Padre, não vos faço uma confissão. Se a Religião manda que nos desafoguemos de nossos pecados, será talvez mais para que recuperemos a paz necessária à alma, que mesmo para que sábios conselhos, seguidos de grandes penitências, nos impeçam de cair de novo em tentação (QUEIROZ, 1991, p. 15).

Em outras palavras, a passagem revela que a personagem crê que o fato de haver uma confissão não a impede de "cair de novo em tentação", ou seja, cometer novamente os mesmos erros, segundo a moral cristã. Logo em seguida, contudo, a personagem declara ao padre: "Pudesse eu, entregando-a [sua lembrançal a vós, libertar-me de tudo que enche a minha memória. Tanta peçonha, tantos malefícios" (QUEIROZ, 1991, p. 15). Com essas duas passagens fica evidente, assim, a concorrência entre dois sentimentos conflituosos que permeiam todo o romance: ao mesmo tempo que Margarida procura paz de espírito devido aos acontecimentos que afligem a sua memória tomada de culpa, há, de sua parte, uma aparente inexistência de arrependimentos. Essa última passagem citada, por exemplo, é carregada de ambiguidade: ela quer se libertar de suas memórias, repletas de "peçonha" e "maleficios", mas ela se considera responsável por essas nocividades? Não fica claro. Outro momento que denota ausência de remorso é a cena em que Margarida e Juliana estão sendo deixadas na ilha:

- [Diz Margarida] Querida aia - disse-lhe. Cem anos que eu viva não apagarão meu arrependimento. As injúrias que sofreste por minha causa!...

Ela cortou:

- Já não será mais o tempo das queixas e do arrependimento. Não estás arrependida. Se aqui estivesse o Senhor João Maria seriam seus braços que irias buscar. Tens medo, e isso é coisa bem diferente.

Calei-me, acabrunhada (QUEIROZ, 1991, p. 40, grifo nosso).

Margarida não se defende quando Juliana a acusa de não carregar arrependimento, o que reafirma a ausência de alguma reconsideração por parte da protagonista. Para Figueiredo (2014), o caminho percorrido pelas personagens femininas que se rebelam e, a exemplo de Margarida, sofrem a devida penitência, tinha um objetivo moralizante. Segundo a autora,

Todas as grandes personagens femininas do
cânone ocidental são rebeldes e apaixonadas,
ousam enfrentar a sociedade patriarcal que
as oprime e as relega à domesticidade sob o
jugo de um marido imposto, desde Tristão e
Isolda até Madame Bovary ou Anna Karenina.
Quase todas morrem no fim do romance (ou são
afastadas para bem longe, como a Capitu bra-
sileira), assim como morrem todas as heroinas
da ópera, como mostrou Catherine Clément,
em L'opéra ou la défaite des femmes. De um
lado, o escritor é fascinado por mulheres fortes,
de outro lado, a doxa exige que elas sejam
condenadas. Considerando que são as mu-
lheres as grandes leitoras de romances, o mau
exemplo é punido para que não seja imitado.
(FIGUEIREDO, 2014, p. 31-32, grifo da autora).

Ainda sobre o padrão de destino dado às mulheres em narrativas literárias, Scholze (2002) afirma que as imagens construidas historicamente em torno da personagem feminina são repetidas ad infinitum. Isso se dá, conforme a autora, inclusive quando se trata de literatura produzida por mulheres. Segundo Scholze, na ficção literária,

[...] as personagens que ousam transgredir as
leis impostas pelas instituições encarregadas
de manter a ordem das coisas são punidas
com finais infelizes, solidão, autonegação da
felicidade, reconhecimento do fracasso no de-
sempenho do papel que que lhes foi confiado
pela sociedade. Tudo isso transparece, recor-
rentemente... num infinito sentimento de culpa,
fracasso, culpa [...]" (SCHOLZE, 2002, p. 181).

Margarida, pode-se afirmar, ousou transgredir o papel feminino, e por isso tem um final infeliz, solitário, com a consciência ocupada por lembranças que a atormentam. Porém, é possivel uma leitura em que não há condenação para Margarida, pois o padre, personagem citado ao longo de toda a narrativa, não tem voz. A protagonista dirige-se a ele a todo momento, mas não é estabelecido diálogo. Logo, se o padre não tem voz, é destituido do poder de estipular qualquer penitência a Margarida. Consequentemente, não há uma voz que a 
repreenda, julgue ou condene. Além disso, o padre em questão foi escolhido como o ouvinte de Margarida pois, diferentemente dos outros religiosos, já havia viajado pelas "terras maravilhosas" - referência direta ao padre André Thevet e suas viagens - e não por qualquer outro motivo. Margarida declara no início do romance:

Se me confio a vós, Padre, é porque sei que entre tantos ministros de Deus, que desta terra não sairam, e julgam o mundo pelo que veem, vós andastes por esse enorme sítio onde Cristo se exilou, e bem conheceis, tanto quanto ao nosso país, as maravilhosas terras que ficam além dos mares, com florestas soberbas e animais estranhos, e criaturas que, semelhantes aos homens, vivem como feras. Confio em que não me havereis por mentirosa, e sedenta de ofuscar os outros com minhas narrativas (QUEIROZ, 1991, p. 15).

Além da ausência de confissão, julgamento e penitência, é possivel estabelecer uma relação também relacionada ao catolicismo - entre o paraíso presente no primeiro livro da Bíblia e o romance. Beauvoir, ao tratar de textos diversos apresentados às meninas durante a infância, afirma que:

A literatura infantil, a mitologia, contos, narrativas, refletem os mitos criados pelo orgulho e os desejos dos homens: é através de olhos masculinos que a menina explora o mundo e nele decifra seu destino. A superioridade masculina é esmagadora: Perseu, Hércules, Davi, Aquiles, Lançarote, Duguesclin, Bayard, Napoleão, quantos homens para uma Joana d'Arc; e, por trás desta, perfila-se a grande figura masculina de São Miguel Arcanjo! Nada mais tedioso do que os livros que traçam vidas de mulheres ilustres: são pálidas figuras ao lado das dos grandes homens; e em sua maioria banham-se na sombra de algum herói masculino. Eva não foi criada para si mesma e sim como companheira de Adão, e de uma costela dele; na Biblia há poucas mulheres cujas ações sejam notáveis [...]. As deusas da mitologia são frivolas ou caprichosas e todas tremem diante de Júpiter; enquanto Prometeu rouba soberbamente o fogo do céu, Pandora abre a caixa das desgraças (BEAUVOIR, 2016, p. 34-35).

Mesmo considerando que tais textos, atualmente, talvez pouco figurem entre as primeiras leituras apresentadas a meninas, as considerações da autora acerca de como as personagens femininas são retratadas ainda são válidas. E, relacionando Margarida às afirmações de Beauvoir, é possivel verificar que o romance superou a Eva criada somente como companheira de Adão, presente no Gênesis. Isso porque, se por um lado Margarida é "expulsa do paraíso" - retirada da expedição - devido ao pecado cometido - o adultério - por outro é ela quem recebe o "Adão", pois João Maria chega à ilha por causa de Margarida, para encontrá-la, e não o inverso. Sobre isso, afirma Brandão (2004) que no espaço do texto literário, construído e produzido no registro masculino, nasce um modelo de heroina literária romântica à disposição do desejo de seu herói. Segundo a autora,

[...] nesse espelho do texto, espelho narcísico,
emerge uma certa miragem da mulher: aquela
tão conhecida nas produções e subproduções
literárias. Enquanto perfeição realizada na be-
leza corporal ou numa pretendida virtude que a
esculpe como amada, esposa e mãe, a mulher
se torna heroina literária. Heroina que acaba se
reduplicando no plano do vivido e tornando-se
modelo a seguir (BRANDÃO, 2004, p. 11).

Logo, o fato de João Maria ser colocado na ilha porque Margarida nela está presente, subverte a heroína à disposição de seu herói. É significativo também o fato de ele ser salvo por Margarida e Juliana; o personagem, submetido à exaustão e quase afogamento após nadar um longo trecho até alcançar a ilha, é retirado do mar com ajuda do xale de Juliana e depois, ferido, é carregado rochedo acima pelas duas mulheres. Assim sendo, elas o salvam, e não ele a elas. Outro fator que vai de encontro à heroina literária romântica apresentada por Brandão é a atuação de Margarida como mãe. Ela não chega a ter filhos com o marido, e não demonstra qualquer anseio pela maternidade - que não é sequer mencionada até o ponto em que a personagem se descobre grávida do amante. Zinani (2006) afirma que o louvor empreendido à maternidade sempre esteve relacionado a um condicionamento social da mulher. Segundo a autora

A maternidade tradicionalmente é vista como a mais nobre missão que a mulher pode exercer. Esse posicionamento estabeleceu-se a partir do século XVIII, quando a maternidade foi estimulada como meio de reduzir a imensa mortalidade infantil. Essa valorização ocorreu por iniciativa do Estado que viu na salvação das crianças um valor mercantil, já que a maior riqueza de um 
país é constituida pela população, inserindo, assim, o culto à maternidade em um discurso econômico. Para atingir esse objetivo, o Estado estimulou que as mulheres cuidassem de seus próprios filhos, pois, dessa maneira, elas seriam felizes e respeitadas (ZINANI, 2006, p. 78-79).

Elisabeth Badinter, em Um amor conquistado: o mito do amor materno (1980), ao questionar a existência do instinto materno - e de qualquer instinto humano - afirma:

Embora muitos cientistas saibam perfeitamente que o conceito de instinto está caduco, alguma coisa em nós, mais forte que a razão, continua a pensar na maternidade em termos de instinto. Teria sido preciso, portanto, citar a definição do dicionário Robert ("tendência inata e poderosa, comum a todos os seres vivos ou a todos os indivíduos de uma mesma espécie"), já que contesto ao mesmo tempo o "caráter inato" do sentimento materno e o fato de que seja partilhado por todas as mulheres. Era preciso lembrar também a definição, ainda mais carregada de pressupostos ideológicos, do Larrouse do século XX (edição de 1971), que descreve o instinto materno como "uma tendência primordial que cria em toda mulher normal um desejo de maternidade e que, uma vez satisfeito esse desejo, incita a mulher a zelar pela proteção física e moral dos filhos", pois acredito que uma mulher pode ser "normal" sem ser mãe, e que toda a mãe não tem uma pulsão irresistivel a se ocupar do filho (BADINTER, 1985, p. 11)

Se a ausência em Margarida do anseio pela maternidade demonstra um distanciamento de um dos papéis atribuidos comumente ao gênero feminino, isso também se relaciona, por outro lado, ao que Frye (1986) coloca como o embate entre autonomia e feminilidade. Conforme a autora, quando é quebrado o modelo convencional da heroína, exibindo uma personagem adulta competente e autônoma, ela não se preocupa ao mesmo tempo com questões referentes aos seus aspectos femininos, dentre eles, inquietações sobre a maternidade. Porém, se à primeira vista Margarida não carrega o desejo de ser mãe, em certo momento de sua gravidez ela anseia pelo nascimento do filho e, quando acontece, ela mostra-se feliz e satisfeita, conforme passagem a seguir que, devido a sua importância, reproduzo-a integralmente:

As dores se repetiam, como relâmpagos atravessando o meu ser. A intervalos vomitava, depois, suarenta, de pegajoso e gelado suor, caía em abatimento, e um sono de minutos se estendia como bênção sobre meu sofrimento. Ao cabo desses instantes despertava sentindo nova dor, mais violenta ainda. Passou-se a noite, chegou a alvorada, e eu sempre das dores recaindo em sonos curtos, até que me veio do corpo uma repentina energia, sorte de raivosa vontade, força que me fazia suportar o sofrer. Sentia já vir a criança; contraia-me toda, perdidamente, de olhos fechados. Punha tenção em acabar eu mesma, com minha própria vontade, aquele martírio. Fechava os olhos: mordia-me nos punhos, geniosa e louca. $\mathrm{Na}$ luta em vencer a própria Natureza, tombavam as horas. Quando fui perdendo as forças e minha cabeça rolava no chão como coisa morta e largada, senti a quentura de uma presença. A lebre, a dois passos de mim, se encolhia como uma velha num xale, com as patinhas sob o corpo e me olhava fixamente. Sorri grata para Filho, e, num limbo de sonho e realidade. percebi o Cabeleira clareando, no teto, toda a cabana. E lá na porta, como estátua mutilada, vi a Dama Verde. Sacudi-me toda, então; não me envergonharia de estar assim numa feira pública, quanto mais diante daqueles duendes; fora-se-me toda espécie de vergonha. Compreendi que o que me molestava então era a cabeça da criança. Chegava já ao fim. E meu filho se soltou, como a noz espremida do fruto. Foi a grave chegada do mistério. Houve uma pausa. Depois, seu choro soou forte. Não sabia o que fazer, estava morta de cansaço mas docemente confortada. Sentia o leito molhado, e eu quase afundando num lago de esquecimento e bem-estar. Mas a voz da lebre sibilou: - As lebres cortam com os dentes essa tira... Referia-se ao umbigo. Lidei com ele. mastiguei-o, rompi-o. Puxei meu filho nu para o meu peito (QUEIROZ, 1991, p. 77).

Segundo Santos, Humbelino e Santos (2017), o parto, durante o século $X X$, devido a sua realização hospitalar e alta medicalização, passou de um "evento fisiológico, familiar onde a mulher era a principal protagonista" (SANTOS; HUMBELINO; SANTOS, 2017, p. 7) a um ato médico, sendo visto como algo patológico e complexo, a partir do qual foi inaugurado um modelo tecnocrático de atendimento. Assim, mesmo considerando o espaço físico e temporal em que acontece o romance, a cena do parto em Margarida também leva em si uma subversão; a mulher é a protagonista e única atuante no processo, pois, abandonada em estágio avançado de gravidez por Juliana e João Maria, passa desacompanhada pelo nascimento de seu filho, contando apenas com apoio das criaturas estranhas que ela vê. Conforme Beauvoir, é próprio das mulheres independentes 
fazer "questão de desempenhar um papel ativo nos momentos que precedem o parto e durante o próprio parto" (BEAUVOIR, 2016, p. 305). Assim sendo, é significativa a opção em narrar uma cena de parto em que a mulher se encontra sozinha. A cena, ainda, revela aspectos mais escatológicos do processo do nascimento - em que Margarida, por exemplo, aproxima-se da animalização ao adotar o procedimento de romper o cordão umbilical com os próprios dentes - afastando o momento da descrição higiênica que muitas vezes the é destinada ou mesmo da total ausência de sua descrição. Conforme Stevens, o parto é "uma experiência que tem estado praticamente ausente na literatura" (2007, p. 6). Segundo a autora, isso se explica como uma tentativa de controlar os processos centrados no corpo da mulher a menstruação, a gestação e o próprio parto feita a partir da criação pelo homem de tabus a respeito de tais processos. Dessa forma, a mulher fica reduzida a uma matéria-prima, puramente corpórea e libidinal, estando, na oposição "natureza - cultura", ligada à natureza - o que teve consequências devastadoras para a mulher e tem uma origem bastante remota: "da liberdade sexual nos estágios primitivos da humanidade à sacralização da castidade e da fragilidade da mulher, são inúmeras e reveladoras as narrativas que tentam explicar/controlar, a força genesiaca do corpo da mulher" (STEVENS, 2007, p. 1).

Mikhail Bakhtin, em seu estudo sobre a obra de Rabelais - A cultura popular na ldade Média e no Renascimento (1965) -, afirma que a gravidez e o parto - assim como o coito, o crescimento corporal, a velhice etc. - devido a sua materialidade imediata, são elementos fundamentais do sistema de imagens pertencentes ao grotesco. Essas imagens, segundo o autor, se colocariam em oposição àquelas clássicas do corpo humano acabado e perfeito (BAKHTIN,1987). E essas imagens, sem dúvida, são contrastantes com a heroina romântica idealizada, dotada somente de beleza e passividade ${ }^{6}$. A presença da cena do parto em Margarida, ainda, vai de encontro ao que mais comumente se tem - ou não se tem - na literatura. Isso porque, além de nos textos literários imperar o silêncio sobre gestação, parto e maternação, a própria mãe, quando surge, tem sua existência - na maior parte dos casos - a partir do momento em que 'produz' uma criança, tendo sua identidade anulada fora dessa diade, fora de seu papel de mãe (STEVENS, 2005). Outro aspecto relacionado à maternidade é que, apesar da origem do nome da protagonista, em nenhum momento ela é comparada a uma santa, à "santa mulher", como é pensada toda boa mãe (BADINTER, 1985). Margarida afasta o filho da aia Juliana meramente por ciúmes, deixando o bem-estar da criança em segundo plano. Essa circunstância, somada à paixão desmedida por João Maria - também causa de ciúmes em relação à aia - faz com que Margarida nos remeta à Medeia de Euripedes - mesmo quando uma Medeia às avessas, como no episódio em que, pouco conhecedora de ervas, ela contribui para o agravamento da doença do filho ao lhe ministrar um chá inapropriado. Além disso, após a morte do filho ela se evade da ilha, resgatada de barco, o que também nos remete à tragédia grega.

Também segundo Frye, "heroines do not kill bears or set out to travel the world, they do not prove themselves in battle or test the boundaries of human survival, they merely fall in love or fail in love" (FRYE, 1986, p. 1). Quando essas afirmações são comparadas à protagonista aqui estudada, Margarida mais uma vez mostra-se como insurgente. Ela, igualmente às heroinas tradicionais, também vivencia a sequência de apaixonar-se para em seguida ter o fracasso amoroso - tanto com Cristiano quanto com João Maria. No entanto, o fracasso no casamento pode ser compreendido como uma transgressão às narrativas que o colocam como o final feliz feminino - o mesmo se dá com a maternidade, pois ela não se constitui, no romance, como o momento de realização plena ou, também, final feliz. Isso porque a união com

\footnotetext{
6 É importante salientar que a maior parte das caracteristicas ligadas a essa heroína era/é atribuida unicamente a uma construção identitária da mulher branca e heterossexual. A realidade das mulheres negras, indígenas, lésbicas etc. difere em muitos aspectos e não é o objeto deste trabalho, visto que a personagem analisada é identificada como branca e heterossexual.
} 
Cristiano é sinônimo de promessas frustradas, ausência de amor e aprisionamento. Beauvoir, ao abordar o casamento, afirma que:

[...] após um periodo de fidelidade mais ou menos longo, a mulher não se detém mais nesses namoros e nessas faceirices. Frequentemente é por rancor que se decide a enganar o marido. [...] o fato é que muitas vezes ela cede menos à sedução do amante do que a um desejo de desafiar o marido. [...] Mas é muitas vezes menos o rancor do que a decepção que a joga nos braços de um amante; não encontra o amor no casamento e resigna-se dificilmente a não conhecer jamais as volúpias e as alegrias cuja espera encantou sua juventude. O casamento, frustrando a mulher de toda satisfação erótica, denegando-lhe a liberdade e a singularidade de seus sentimentos, a conduz, através de uma dialética necessária e irônica, ao adultério (BEAUVOIR, 2016, p. 355).

Margarida, de fato, utiliza suas queixas contra o marido como justificativa quando é confrontada por Juliana acerca do adultério:

[Diz Margarida] - Levanta-te! Acalma-te! Que defensora és de Cristiano! Sempre pensei que o detestasses. Lembra-te, quando pintava de branco as solas das minhas sandálias, proibindo-me de sair, como se eu fosse uma escrava? Lembra-te, quando ceava com outros homens, e me deixava presa no quarto? E agora, pensa bem. Certamente Cristiano terá morrido! E, se não morreu, como é de todo provável, estará com as mulheres de faces riscadas, e seus filhotes ferozes... Tu mesma o dizias... (QUEIROZ, 1991, p. 32).

Conforme aponta Beauvoir, assim, a decepção com o marido, e com a vida que imaginou que teria com ele, mas não teve, é um dos fatores principais que levam Margarida pelo percurso que lhe apresenta o amante. Outro ponto em que Margarida contraria as heroínas descritas por Frye é o fato de a personagem passar por testes de sobrevivência, sobretudo depois da morte de seus companheiros de exilio. Além disso, é dela, reitero, a iniciativa de participar da expedição maritima, motivada por seu interesse pessoal no misterioso que envolvia as 'novas terras'. Contudo, se, por um lado, a narrativa subverte o modelo de personagem feminina tradicional, por outro, ele reafirma um padrão repetidamente utilizado como causa de rivalidade feminina: a disputa por um homem. Segundo Tiburi, a rivalidade feminina
Trata-se de um mito próprio da ideologia da dominação masculina que se sustenta em mil invenções sobre uma suposta natureza feminina avessa à condição das mulheres como seres capazes de apoiar e ajudar umas às outras. Ora, a manutenção do poder patriarcal precisa que se evitem certos pensamentos e ações que as mulheres possam ter. A união das mulheres é tida nesse contexto como um perigo que se deve evitar (TIBURI, 2016, p. 7).

Mesmo que a disputa entre as duas personagens não se concretize, pois não é consumado um relacionamento amoroso e/ou sexual entre Juliana e João Maria - logo ela não 'compete' por ele - Margarida é tomada de desconfianças em relação à sua aia que, desgostosa pelo tratamento hostil que sua protegida passa a lhe dirigir, suicidase. Depois da morte de João Maria, no entanto, se estabelece uma disputa entre as duas, agora por Joãozinho: "A compreender estais, Padre, que eu trocara os zelos de João Maria pelos de Joãozinho, e em cegueira de alma. Era disputa feroz e quase silenciosa, aquela, entre mim e Juliana" (QUEIROZ, 1991, p. 96). Além disso, podese pensar na prática de opressão de Margarida em relação à Juliana devido à posição social: mesmo quando abandonadas na ilha, o tratamento dispensado à aia é sempre de subalternidade. Ainda que isso mude com o decorrer da narrativa, no primeiro momento na ilha João Maria tem a aia como subordinada à Margarida e, por direito, a ele próprio.

Este [João Maria] pegou-me pela mão esquer$\mathrm{da}$, enquanto que com a direita brandia no ar a sua espada, olhando-a confiantemente:

- Vamos conhecer a ilha - disse-me.

E, voltando-se secamente para Juliana:

- Põe as roupas a secar, e espera-nos neste lugar mesmo. Cuida de tudo! Estou tão bem disposto como depois de ter ganha uma batalha.

$A$ aia voltou-se para mim:

- Menina Margarida, não me deixes sozinha! Pode vir uma grande fera... que sei lá...

- Fica-te e deixa-te de resmungos, Juliana ordenou João Maria, desta vez mais autoritário.

Apertando o braço de meu amado, depressa sai dala sem sentir nenhuma pena de Juliana, que fazia, de propósito, um triste semblante (QUEIROZ, 1991, p. 48). 
Margarida em nenhum momento contesta João Maria em defesa de Juliana. Em outra ocasião, ainda, ele afirma que seria bom se Juliana morresse e, muito fracamente, Margarida a protege afirmando que a aia era útil como cozinheira, ao que em seguida pensa consigo mesma: " $E$ já atraiçoava a amizade de minha boa Juliana, louvando-a só em sua utilidade, porque é covarde a alma de qualquer mulher amorosa, diante de seu amor" (QUEIROZ, 1991, p. 49). Quando, no entanto, o relacionamento entre João Maria e a aia torna-se amigável, Margarida é tomada de ciúmes em relação à mulher que zelou por ela durante toda a vida - fato que também ratifica o já mencionado padrão da rivalidade feminina. A narrativa, assim, retrata o relacionamento entre as duas mulheres como desleal, instável e rúptil, reiterando a crença patriarcal de que as amizades femininas nunca são plenamente genuínas. Segundo Beauvoir, a rivalidade entre mulheres é recorrente na literatura: "o tema da mulher enganada pela sua mulher amiga não é apenas um lugar-comum literário; quanto mais duas mulheres são amigas, mais perigosa se torna a dualidade" (BEAUVOIR, 2016, p. 351). Logo, o romance estudado, nesse ponto, não supera o lugar-comum apontado por Beauvoir.

Apesar disso, as atitudes de Margarida, em sua maior parte, não se adequam aos clichês literários. Ela contradiz as heroínas românticas que primeiro se anunciavam: belas, delicadas, passivas, perfeitas - caracteristicas restritivas que terminam por confinar as mulheres em esferas de comportamento limitadas e obrigatórias. Contradiz também as heroínas de tempos menos remotos em que o padrão sequencial da vida de uma personagem feminina - que mostrava algum tipo de autonomia - era sempre a passagem do fracasso amoroso ao ostracismo, representado muitas vezes pela loucura e/ou pela morte. Margarida La Rocque, assim como outras obras que a antecederam, ou mesmo sucederam, coloca-se assim como um romance de uma fase de transição. Com o objetivo de confirmar e demonstrar essa constatação, foi proposta uma leitura em que se analisaram as características da personagem feminina, além de suas vivências e ações referentes à sua condição enquanto mulher em alguns dos principais momentos de sua trajetória. Nessa discussão, o fato de a mulher ser a narradora é um elemento de grande importância, pois, conforme aponta Frye (1986), uma personagem feminina que conta a própria história é sempre algo subversivo.

Dinah Silveira de Queiroz, apesar de pouco lida e estudada atualmente, deixou grande contribuição à literatura brasileira, principalmente no que diz respeito à autoria feminina e à construção de personagens mulheres. Assim sendo, este trabalho, por fim, também buscou trazer uma contribuição, ainda que breve, ao resgate da obra de Dinah, que aqui vem representar todas as mulheres escritoras esquecidas ou apagadas da literatura.

\section{Referências}

BADINTER, Elisabeth. Um amor conquistado: o mito do amor materno. Tradução Waltensir Dutra. Rio de Janeiro: Nova Fronteira, 1985.

BAKHTIN, Mikhail. A cultura popular na ldade Média e no Renascimento: o contexto de François Rabelais. Tradução Yara Frateschi Vieira. São Paulo: Hucitec; Brasilia: Editora da Universidade de Brasilia, 1987.

BEAUVOIR, Simone. O segundo sexo. Tradução Sérgio Milliet. 3. ed. São Paulo: Nova Fronteira, 2016. 2 v. v.2: A experiência vivida.

BENVENISTE, Émile. Problemas de linguistica geral I. Tradução Maria da Gloria Novak e Maria Luiza Neri. 3. ed. Campinas: Pontes Editora da Universidade Estadual de Campinas, 1991. https://doi.org/10.20396/ sinteses.voi7.10244

BOURNNEUF, Roland; OUELLET, Réal. Universo do romance. Tradução José Carlos Seabra Pereira. Coimbra: Livraria Almedina, 1976.

BRANDÃO, Ruth Silviano. Passageiras da voz alheia. In: BRANDÃO, Ruth Silviano; CASTELLO BRANCO, Lucia. A mulher escrita. Rio de Janeiro: Lamparina, 2004. p. 11-14.

CALLADO, Ana Arruda. 450 anos de rivalidade. In: THEVET, André. A cosmografia universal de André Thevet, cosmógrafo do rei. Tradução Raul de Sá Barbosa. Rio de Janeiro: Fundação Darcy Ribeiro, 2009. p. 19-23.

COELHO, Nelly Novaes. A literatura feminina no Brasil contemporâneo. São Paulo: Siciliano, 1993.

COELHO, Nelly Novaes. A literatura feminina no Brasil - das origens medievais ao século XX. In: DUARTE, Constância Lima; DUARTE, Eduardo de Assis; BEZERRA, Kátia da Costa (org.). Gênero e representação: teoria, história e crítica. Belo Horizonte: UFMG, 2002. p. 89-107. https://doi.org/10.1590/1980436920170000000017 
DUARTE, Constância Lima. A literatura de autoria feminina e os anos 30 no Brasil. Araticum, Montes Claros, v. 14, n. 2, p. 9-24, 2016. Disponivel em: http:// www.revistaaraticum.unimontes.br/index.php/araticum/article/view/253/224. Acesso em: 15 maio 2018.

DUARTE, Constância Lima. Feminismo e literatura no Brasil. Estudos Avançados, São Paulo, v. 17. n. 49, set./dez. 2003. Disponivel em: http:// www.scielo.br/scielo.php?script=sci_arttext\&pid $=$ S0103-40142003000300010. Acesso em: 23 maio 2018. https://doi.org/10.1590/s010340142003000300010

DUARTE, Constância Lima. Literatura feminina e crítica literária. In: Encontro Nacional da ANPOLL, 2., 1987, Rio de Janeiro. Disponivel em: https://periodicos.ufsc.br/index.php/travessia/article/download/17198/15769. Acesso em: 9 maio 2016. p. 15-23.

FIGUEIREDO, Eurídicie. História literária e crítica feminista: figurações das mulheres. In: SILVA, Antônio de Pádua Dias da (org.). Memórias da Borborema 3: Feminismo, estudos de gênero e homoerotismo. Campina Grande: Abralic, 2014. p. 27-46.

FRYE, Joanne. Living stories, telling lives. Ann Arbor: The University of Michigan Press, 1986.

GÂNDARA, Paula. O sexo do verbo?... In: DUARTE, Constância Lima; DUARTE, Eduardo de Assis; BEZERRA, Kátia da Costa (org.). Gênero e representação na Literatura Brasileira. Belo Horizonte: Pós-graduação em Letras: Estudos Literários, UFMG, 2002. p. 43-57. https://doi.org/10.12957/matraga.2017.30189

GENETTE, Gérard. Discurso da narrativa. Tradução Fernando Cabral Martins. Lisboa: Vega, [1976?].

HANCIAU, Nubia. A feiticeira no imaginário ficcional das Américas. Rio Grande: Editora da Furg, 2004.

MUZART, Zahidé Lupinacci. A ascensão das mutheres no romance. In: ARRUDA, Aline Alves et al. A escritura no feminino: aproximações. Florianópolis: Editora Mulheres, 2011. p. 17-27.

PINTO, Cristina Ferreira. O Bildungsroman feminino: quatro exemplos brasileiros. São Paulo: Perspectiva, 1990.

QUEIROZ, Dinah Silveira de. Margarida La Rocque: a itha dos demônios. 6. ed. Rio de Janeiro: Record, 1991

SANTOS, Adriana Correia dos; HUMBELINO, Taynara Morais; SANTOS, Irenilda Angela dos. Nós Sabemos Parir: o direito ao parto humanizado e o protagonismo da mulher. In: CONGRESSO INTERNACIONAL DE POLITICA SOCIAL E SERVIÇO SOCIAL: DESAFIOS CONTEMPORÂNEOS, 2.; SEMINÁRIO NACIONAL DE TERRITÓRIO E GESTÃO DE POLITICAS SOCIAIS, 3.; CONGRESSO DE DIREITO À CIDADE E JUSTIÇA AMBIENTAL, 2., 2017, Londrina. Anais eletrônicos [...] Londrina: Universidade Estadual de Londrina, 2017. Disponivel em: https://www.congressoservicosocialuel.com. br/anais/2017/assets/134181.pdf. Acesso em: 18 maio 2018. https://doi.org/10.4025/6cih.pphuem.668
SCHMIDT, Rita Terezinha. Da exclusão, da imitação e da transgressão: o caso Celeste, de Maria Benedita Bormann. In: SCHMIDT, Rita Terezinha. Descentramentos/convergências: ensaios de crítica feminista. Porto Alegre: Editora da UFRGS, 2017. p. 319-355

SCHOLZE, Lia. A mulher na literatura: gênero e representação. In: DUARTE, Constância Lima; DUARTE, Eduardo de Assis; BEZERRA, Kátia da Costa (org.). Gênero e representação na Literatura Brasileira. Belo Horizonte: Pós-graduação em Letras: Estudos Literários, UFMG, 2002. p. 174-182. https://doi. org/10.22409/rg.v3i1.255

SHOWALTER, Elaine. A critica feminista no território selvagem. Tradução Deise Amaral. In: HOLLANDA, Heloisa Buarque de (org.). Tendências e impasses: O feminismo como crítica da cultura. Rio de Janeiro: Rocco, 1994. p. 23-57.

SHOWALTER, Elaine. Toward a feminist poetics. In: SHOWALTER, Elaine (org.). The new feminist criticism: essays on women, literature, and theory. New York: Pantheon Books, 1985. p. 125-143. https://doi. org/10.1525/ess.1985.5.1.77

SILVA, Jacicarla Souza da. Crítica feminista no Brasil. In: SILVA, Jacicarla Souza da. Vozes femininas da poesia latino-americana: Cecilia e as poetisas uruguaias. São Paulo: Editora UNESP; São Paulo: Cultura Acadêmica, 2009. Disponivel em: http://books. scielo.org/id/3vjgm/pdf/silva-9788579830327-04. pdf. Acesso em: 15 nov. 2017. p. 41-49. https://doi. org/10.7476/9788579830327

SONNET, Martine. Uma filha para educar. In: DUBY, Georges; PERROT, Michelle (coord.). História das mulheres no Ocidente. Tradução Alda Maria Durães et al. Porto: Edições Afrontamento, 1991. 5 V. v.3, p. 141-179.

STEVENS, Cristina Maria Teixeira. O corpo da mãe na literatura: uma ausência presente. In: STEVENS, Cristina Maria Teixeira; SWAIN, Tania Navarro (org.) A construção dos corpos: perspectivas feministas. Florianópolis: Editora Mulheres, 2007. p. 85-116.

STEVENS, Cristina Maria Teixeira. Ressignificando a maternidade: psicanálise e literatura. Gênero, Niterói, v. 5, n. 2, p. 1-15, 2005. Disponivel em: http://www.revistagenero.uff.br/index.php/revistagenero/article/ view/385/289. Acesso em: 22 ago. 2018

TACCA, Oscar. As vozes do romance. Tradução Margarida Coutinho Gouveia. 2. ed. Coimbra: Almedina, 1983

TIBURI, Marcia. Prefácio. In: SOUZA, Babi. Vamos juntas? O guia da sororidade para todas. Rio de Janeiro: Galera Record, 2016. p. 7-10.

XAVIER, Elódia. A hora e a vez da autoria feminina: de Clarice Lispector a Lya Luft. In: DUARTE, Constância Lima; DUARTE, Eduardo de Assis; BEZERRA, Kátia da Costa (org.). Gênero e representação na Literatura Brasileira. Belo Horizonte: Pós-graduação em Letras: Estudos Literários, UFMG, 2002. p. 157-166. https:// doi.org/10.11606/issn.2237-1184.voi25p38-52

ZINANI, Cecil Jeanine Albert. Literatura e gênero: a construção da identidade feminina. Caxias do Sul: Educs, 2006. https://doi.org/10.17851/23589787.27.2.317-324 
ZOLIN, Lúcia Osana. A construção da personagem feminina na literatura brasileira contemporânea (re) escrita por mulheres. Revista Diadorim, Rio de Janeiro, v. 9, p. 95-105, jul. 2011. Disponivel em: https://revistas.ufrj.br/index.php/diadorim/article/view/3923. Acesso em: 15 nov. 2017. https://doi.org/10.35520/ diadorim.2011.v9noa3923.

\section{Endereço para correspondência}

\section{Ana Cristina Steffen}

Pontificia Universidade Católica do Rio Grande do Sul

Av. Ipiranga, 6681

Partenon 97010-082

Porto Alegre, RS, Brasil

\section{Ana Cristina Steffen}

Licenciada em Letras - Lingua Portuguesa e respectivas Literaturas pela Pontifícia Universidade Católica do Rio Grande do Sul (PUCRS), Porto Alegre, RS (2017). Mestre em Teoria da Literatura pela mesma universidade, bolsista do Conselho Nacional de Desenvolvimento Científico e Tecnológico (CNPq). Atualmente, doutoranda em Teoria da Literatura também pela PUCRS, bolsista da Coordenação de Aperfeiçoamento de Pessoal de Nivel Superior (CAPES). 